\title{
Are soft tissue therapies beneficial for patients diagnosed with head and neck cancer?
}

\begin{abstract}
There is a widely acknowledged and steadily rising incidence rate of head and neck tumours. Consequently, the overall quality of life of patients suffering from such tumour locations has significantly deteriorated, while attendant treatment costs remain on the rise. Advances in modern surgical techniques are believed to appreciably improve the prognosis, though. At the same time, a pursuit of invasive anti-cancer treatment results in many structural and functional changes in those patients, warranting application of select physiotherapy management. This manuscript presents a patient diagnosed with neck tumours in whom physiotherapy regimen comprising the select soft tissue therapy techniques was applied. The implemented physiotherapeutic intervention proved instrumental in achieving an appreciable improvement with regard to a majority of variables under study.
\end{abstract}

Palliat Med Pract 2018; 12, 4: 203-206

Key words: soft tissue therapy, neck cancer, physiotherapy

\section{Abbreviations}

MFR - myofascial release

$\mathrm{PR}$ - post-isometrical relaxation

$\mathrm{SR}$ - stabilizing reversals

PNF - proprioceptive neuromuscular facilitation

$\mathrm{RI}$ - reciprocal inhibition

MET - muscle energy techniques

SS - satisfaction scores in the range from -3 to +3 , where: $-3-$ total dissatisfaction with the applied treatment, $0-$ no changes reported whatsoever, $+3-$ total satisfaction with the applied treatment ESAS - Edmonton Symptom Assessment System

\section{Introduction}

The head and neck are the highly specialized parts of the human body. Relatively small-sized in proportion to the rest of the body, they accommodate nevertheless a number of key structures controlling the senses and various life functions [1]. Any cancer invading this strategic area, in conjunction with an invasive anti-cancer treatment (surgical intervention, chemotherapy, radiotherapy) appreciably contribute to many attendant tissue dysfunctions, i.e. myofascial, nervous and vascular disorders that may significantly affect overall quality of life, as well

\footnotetext{
Adres do korespondencji:

Anna Pyszora

Chair and Department of Palliative Care,

Nicolaus Copernicus University,

Collegium Medicum, Bydgoszcz, Poland

e-mail: aniap30@wp.pl

V M Palliative Medicine in Practice 2018; 12, 4, 203-206

Copyright (C) Via Medica, ISSN 2545-0425

DOI: 10.5603/PMPI.2018.0012
} 
as require that several additional measures must be provided for and applied within the physical rehabilitation process, with a view to recovering the patients' functional capabilities. This is particularly essential when facing up the increasing incidence of the cancer of the larynx, oral cavity, tongue, and throat [1, 2].

Soft tissue therapy entails application of manual release techniques aimed at reducing the muscle tension, enhancing the overall mobility of the soft tissues (i.e. eliminating restrictions in tissue sliding) and reducing myofascial pain [3]. Making use of this form of therapy is a vital component of adjuvant treatment in those patients. In the course of the anticancer therapy some muscles, individual fascia layers, subcutaneous tissue, and skin may become either damaged or surgically removed, consequently resulting in the formation of extensive scarring [4].

The aim of this case report is to demonstrate appreciable benefits of soft tissue manual therapy in a patient who suffers from the neck cancer and had completed an anti-cancer treatment at least three months prior to its commencement.

\section{Case report}

The patient was a 59-year old man, pursuing a white-collar job. He was first subjected to an anti-cancer treatment in 2001 due to the squamous cell carcinoma of the larynx, whereupon a chordectomy was carried out which adversely affected overall sonority of his voice. In the subsequent years (2010) cancer of the lower and middle throat was diagnosed, with metastases to the lymph nodes on both sides of the neck. Surgical intervention facilitated the removal of a throat tumour, lymph nodes on both sides of the neck, tonsils, left-hand side submandibular gland, and partially - the root of the tongue. Subsequently, the patient received chemotherapy and radiotherapy, even though he was not put on a permanent pharmacotherapy.

Upon examination, the patient rated his pain level at " 0 ", as expressed by the NRS (numerical rating scale: $0-$ no pain, $10-$ the most severe pain). The patient's principal complaint consisted of the paroxysmal acute pain located within the shoulder and the clavicular angle, caused by rapid changes in outdoor temperature, as well as in the ambient indoor temperature. On Karnofsky performance status ( 0 - death, 100 - fully active), the patient scored 80 , whereas on the ESAS ( 0 - no symptom present, the best well-being, 10 - the most severe symptom, the poorest well-being) the severity of symptoms was expressed as follows: lack of appetite (7), dry mouth (6), well-being (4), tiredness (4), sleep problems (3), depression (2).
In the study of the absolute and relative mobility of the cervical spine, appreciable limitations were encountered, i.e. flexion, extension, lateral flexing to the right, lateral flexing to the left, rotation to the left, rotation to the right.

The physiotherapeutic intervention comprised 6 sessions of soft tissue manual therapy.

A single session lasted 30 minutes, and took place twice a week.

The following techniques were applied throughout each session:

- MFR: the upper part of the trapezius muscle, semispinalis and splenius capitis, base of the skull, releasing the scar tissue, sternocleidomastoid muscle, infra- and suprahyoid muscles;

- PR: the upper part of the trapezius muscle, sternocleidomastoid muscle, suboccipital muscles;

- SR in line with the scapular pattern, in the correct head position in compliance with the PNF method which supplemented the manual therapy.

Following the intervention, the following changes in the variables under study, as presented in Table 1, were observed.

The patient experienced a general improvement in the area subjected to the therapy and rated overall effectiveness of the therapy as high.

\section{Discussion}

Research on the impact of the soft tissue manual therapy, as applied in cancer patients, is still rather scarce. Studies published to date highlight that cancer patients suffer from numerous ailments that can effectively be treated with soft tissue manual therapy. This applies to both the convalescent patients, and those in palliative care [5-13].

The results yielded by the presented case demonstrate that myofascial relaxation techniques, muscle energy techniques, stretching, and scar treatment, may become effective remedies in alleviating a number of ailments associated with the anti-cancer treatment. With regard to the patient at issue, the change in the range of movement consisted primarily in the extension and lateral flexion of the cervical spine. This was owed to the release of the tissues of the anterior surface of the neck in which, due to radiotherapy and scarring, the greatest restrictions were encountered. A slight decrease in the rotation range to the right may have been attributable to a measurement error. Significantly, an overall rate of incidents of acute pain found within the shoulder and the clavicular angle decreased. Furthermore, the patient reported a slight improvement in his appetite. 
Table 1. The effects of the applied therapy

\begin{tabular}{|c|c|}
\hline Subjective & \\
\hline Positive & Negative \\
\hline $\begin{array}{l}\text { Loosening of the neck, a sense of free movement } \\
\text { - Improvement in the mobility of the scar tissue and } \\
\text { - } \text { skin } \\
\text { - } \text { within the shoulder and the clavicular angle } \\
\text { - Improved appetite } \\
\text { - (ESAS } 7 \rightarrow 5) \\
\text { - Increased activity Karnofsky }(80 \rightarrow 90) \\
\text { - Satisfaction with the effects of therapy }(\mathrm{SS},+3)\end{array}$ & $\begin{array}{l}\text { - Improvement in well-being } \\
\text { (ESAS } 4 \rightarrow 5 \text { ) }\end{array}$ \\
\hline Objective & \\
\hline Positive & Negative \\
\hline $\begin{array}{l}\text { - Increase in the absolute range of motion: flexion, } \\
\text { extension, lateral flexion, rotation to the left } \\
\text { - Increase in the relative range of motion: extension, } \\
\text { lateral flexions, rotation to the left }\end{array}$ & $\begin{array}{l}\text { - Reduction in the absolute range of motion: rotation } \\
\text { to the right } \\
\text { - Reduction in the relative range of motion: rotation to } \\
\text { the right }\end{array}$ \\
\hline
\end{tabular}

It is well-worth noting that the physiotherapeutic intervention was relatively short in duration, the six $30 \mathrm{~min}$ therapy sessions, spread over a three-week period, only. Nevertheless, within such a short time, an appreciable improvement was secured in terms of both subjective self-assessment (ESAS), as well as a clear improvement in the scope of objective variables under study, e.g. range of joint mobility and performance status (Karnofsky). The level of satisfaction with the applied treatment was evaluated as very high. This gives grounds to believe that the therapy must have exerted a tangible impact on the patient's daily activities.

Indubitably, it would be prudent to pursue research on the large groups of cancer patients, as this would be conducive to assessing the overall effectiveness of individually applied soft tissue manual techniques with much higher credibility. This is a well-grounded postulate, considering that over $30 \%$ of patients subjected to radical surgical intervention are believed to suffer from chronic pain associated with the on-going anti-cancer treatment [14].

Soft tissue manual techniques rate among the much-underrated methods of prevention and alleviation of ailments in the myofascial system. Notably, in many areas of physical rehabilitation, soft tissue therapy is widely applied, while the studies assessing its effectiveness report promising results [15].

Development of uniform guidelines on the application of manual soft tissue techniques in the adjuvant therapy to the cancer treatment would be instrumental in designing and structuring comprehensive, target-oriented rehabilitation programmes for cancer patients, irrespective of the actual location of the disease.

\section{References}

1. Aleksandrowicz R, Ciszek B. Anatomia kliniczna głowy i szyi. In: Mięśnie i powięzie głowy, szyi i karku. Wydawnictwo Lekarskie PZWL, Warszawa 2007: 126-156.

2. Rettig EM, D'Souza G. Epidemiology of head and neck cancer. Surg Oncol Clin N Am. 2015; 24(3): 379-396, doi: 10.1016/j.soc.2015.03.001, indexed in Pubmed: 25979389.

3. Manheim C. The Myofascial Release Manual. 4th ed. Slack 2008: 2-12.

4. Marszałek S. Fizjoterapia w ograniczeniach ruchomości stawowej i tkankowej po leczeniu nowotworów złośliwych. In: Woźniewski M. ed. Fizjoterapia w onkologii. Wydawnictwo Lekarskie PZWL, Warszawa 2012: 65-75.

5. Genden EM, Ferlito A, Shaha AR, et al. Complications of neck dissection. Acta Otolaryngol. 2003; 123(7): 795-801, indexed in Pubmed: 14575393.

6. Hawro B, Majcher P, Nyka W, Woźniewski M. Fizjoterapia chorych poddanych radioterapii. In: Woźniewski $M$, ed. Fizjoterapia w onkologii. Wydawnictwo Lekarskie PZWL, Warszawa 2012: 22-30.

7. Chua KS, Reddy SK, Lee MC, et al. Pain and loss of function in head and neck cancer survivors. J Pain Symptom Manage. 1999; 18(3): 193-202, indexed in Pubmed: 10517041.

8. Pyszora A, Budzyński J, Wójcik A, et al. Physiotherapy programme reduces fatigue in patients with advanced cancer receiving palliative care: randomized controlled trial. Support Care Cancer. 2017; 25(9): 2899-2908, doi: 10.1007/s00520-017-3742-4, indexed in Pubmed: 28508278.

9. Cantarero-Villanueva I, Fernández-Lao C, Del Moral-Avila R, et al. Effectiveness of core stability exercises and recovery myofascial release massage on fatigue in breast cancer survivors: a randomized controlled clinical trial. Evid Based Complement Alternat Med. 2012; 2012: 620619, doi: 10.1155/2012/620619, indexed in Pubmed: 21792370.

10. Pyszora A, Wójcik A, Krajnik M. Are soft tissue therapies and Kinesio Taping useful for symptom management in palliative care? Three case reports. Adv Palliat Med. 2010; 9(3): 87-92.

11. Myers EM. Head and neck oncology. Diagnosis, treatment and rehabilitation. Little\&Brown 1991: Radiotherapy 167-176, Neck Dissection 323-325. 
12. Marszałek S, Golusinski W, Dworak LB. [Assessment of stretching techniques for neck and arms muscles in physiotherapy following total laryngectomy]. Otolaryngol Pol. 2004; 58(3): 485-491, indexed in Pubmed: 15311591.

13. Wójcik A, Marszałek S, Pyszora A, et al. The application of osteopathy and manual therapy in oncology and palliative care. Dysfunctions of the Locomotor System. The Role of Osteopathy and Manual Therapy in the Treatment of Soft Tissue. Title of the journal. 2010; 1: 40-51.
14. van den Beuken-van Everdingen MHJ, de Rijke JM, Kessels $A G$, et al. Prevalence of pain in patients with cancer: a systematic review of the past 40 years. Ann Oncol. 2007; 18(9): 1437-1449, doi: 10.1093/annonc/mdm056, indexed in Pubmed: 17355955.

15. Ajimsha MS, Al-Mudahka NR, Al-Madzhar JA. Effectiveness of myofascial release: systematic review of randomized controlled trials. J Bodyw Mov Ther. 2015; 19(1): 102-112, doi: 10.1016/j.jbmt.2014.06.001, indexed in Pubmed: 25603749. 